\title{
IMPLEMENTASI STRATEGI EVERYONE IS A TEACHER HERE DALAM MENINGKATKAN PRESTASI BELAJAR BIDANG STUDI QUR'AN HADIST PADA SISWA PROGRAM AKSELERASI KELAS XI DI MAN KOTA KEDIRI 3
}

\author{
NUR FADLILAH \\ MTSS Darul Hikmah Beji Jogoroto Jombang \\ Email : humaid.pasca@gmail.com
}

\begin{abstract}
ABSTRAK
Peserta didik merupakan individu individu yang berbeda dan memiliki karakteristik tertentu, hal ini terkadang belum disadari oleh beberapa guru sebagai pendidik. Oleh karena itu kebanyakan pendidik menggunakan metode yang cenderung sama dan pasif dalam membangun proses pembelajaran.Untuk itu perlu upaya mengembangkan beberapa metode pembelajaran agar tercapai hasil pendidikan yang maksimal. Penjabaran penelitian ini menggunakan pendekatan kualitatif naturalistik dengan penerapan metode everyone is a teacher here pada mata pelajaran Qur'an Hadist kelas XI. Metode ini didilakukan untuk peningkatan mutu kelas akselerasi di MAN 3 Kediri dengan memperhatikan data nilai tertinggi 88, nilai terendah 62, nilai rata-rata 78 dengan prosentase ketuntasan 63,15\%. Dari 19 siswa yang tuntas belajar mencapai 12 siswa dan tidak tuntas mencapai 7 siswa. Penerapan Metode everyone is teacher setidaknya dapat diketahui peningkatan daya serap atau penguasaan materi sesuai dengan ketuntasan maksimal sebagai berikut; siswa yang tuntas ada 17 siswa dan belum tuntas 2 siswa. Dengan nilai tertinggi 88 , nilai terendah 74 , dan nilai rata-rata 81,47 . prosentase siswa yang tuntas $89,47 \%$. Metode everyone is teacher dapat membantu memaksimalkan pembelajaran yang dilakukan sehingga capaian hasil proses belajar mengajar menjadi meningkat.
\end{abstract}

Kata Kunci : Metode Everyone is a teacher here, Akselerasi,Prestasi Belajar

\section{PENDAHULUAN}

Pendidikan salah satu aspek penting dalam kehidupan manusia, dimana terjadi proses dialektik pengetahuan dan nilai nilai sosial yang senantiasa berkembang di dalamnya. Pendidikan merupakan suatu proses seseorang untuk mengembangkan kemampuan, sikap, dan tingkah laku lainnya dalam masyarakat. Dalam hal ini pendidikan berusaha mengembangkan potensi individu agar mampu berdiri sendiri. Untuk mencapai tujuan tersebut, pendidikan melakukan usaha yang terencana dalam memilih isi atau meteri, strategi, dan teknik penilaian yang sesuai (Nanang Fatah, 1996 : 5)Untuk itu pelaksanaan proses belajar mengajar menjadi sangat penting dalam mencetak generasi yang akan datang. Maka dalam proses belajar mengajar harus diupayakan semaksimal mungkin dalam meningkatkan kualitas hasil belajar. Beberapa metode yang dilakukan pendidik sangat berpengaruh terhadap situasi dan kualitas pembelajaran. Metode yang monoton akan membuat pembelajaran tidak menarik dan menjenuhkan. Kombinasi metode perlu dilakukan untuk menarik minat peserta didik dalam belajar sehingga terjadi take and give antara guru dan siswa menjadi maksimal. Disinilah terjadinya keaktifan siswa menjadi hal yang penting dalam pembelajaran. Dalam konsep active learning juga dinyatakan bahwa keaktifan siswa dalam belajar sangat menentukan kualitas pembelajaran sebagaimana yang dikutip oleh Umi Machmudah dalam bukunya yang berjudul Active Learning dalam Pembelajaran Bahasa Arab, menyatakan bahwa: Pembelajaran pada dasarnya merupakan upaya untuk mengarahkan anak didik ke dalam proses belajar, sehingga mereka dapat memeperoleh tujuan belajar sesuai dengan apa yang diharapkan. Pembelajaran hendaknya mempertahankan kondisi individu anak, karena merekalah yang akan belajar. Anak didik merupakan individu yang berbeda satu sama lain, memiliki keunikan masing-masing yang tidak sama dengan orang lain (Umi Machmudah, 2003:2).

Mengingat keaktifan dan kemampuan siswa berbeda antara satu dengan lainnya, maka perlu suatu upaya dilakukan untuk mendapatkan kualitas pembelajaran.Kualitas pembelajaran dapat dilihat dari beberapa indikator, antara lain aktifnya siswa dalam mengikuti proses 
pembelajaran.Hal ini menunjukkan belajar merupakan proses dialog, komunikasi, serta proses perubahan perilaku dan interaksi sosial(Slameto, 2003:2)..Untuk itu perlu diupayakan peningkatan mutu dan kualitas hasil pembelajaran khususnya pada mapel Qur'an Hadist kelas XI di lingkungan MAN 3 kediri

Salah satu upaya untuk meningkatkan kualitas belajar pada Mapel Qur'an Hadist kelas XI MAN 3 Kediri dengan menggunakan metode everyone is teacher pada kelas akselerasi guna meningkatkan hasil belajar. Everyone is a teacher here adalah suatu strategi yang memberi kesempatan pada setiap peserta didik untuk bertindak sebagai "pengajar" terhadap peserta didik lain ( Ramayulis, 2005:15). Dengan menggunakan metode everyone is a teacher here dalam pembelajaran, siswa akan dilatih untuk bertanggung jawab dan meningkatkam kemamuan dalam mengemukakan pendapat, menganalisis masalah dan ketrampilan membuat simpulan. Setiap siswa diharapkan dapat menguasai suatu pokok bahasan tertentu sehingga dapat menjawab setiap pertanyaan dan didapatkannya Metode ini memberi kesempatan kepada siswa untuk berperan aktif sebagai guru bagi kawan-awannya (Menurut agus suprijono: 2012). Siswa yang selama ini tidak mau terlibat aktif dalam pembelajaran, akan ikut serta dalam pembelajaran aktif. Hal ini penting dilakukan karena berdasar data yang ada nilai Quran Hadith pada siswa kelas XI program Akselerasi MAN Kota Kediri 3. Sebagaimana yang penulis ketahui hasil belajar siswa dapat diketahui dari nilai tertinggi 88 , nilai terendah 62 , nilai ratarata 78 dengan prosentase ketuntasan $63,15 \%$. Hal ini jika dilihat dari KKM (Kriteria Ketuntasan Maksimal) yang ditetapkan oleh sekolah pada mata pelajaran Quran Hadith adalah 80. Dari 19 siswa yang tuntas belajar untuk sementara masih mencapai 12 siswa dan yang tidak tuntas mencapai 7 siswa.

Dari uraian yang telah dijabarkan di atas penulis mendapati kemungkinan bahwa dengan menggunakan strategi everyone is a teacher here (semua bisa jadi guru) akan memberikan prestasi belajar yang lebih baik pada mata pelajaran Quran Hadith. Prestasi yang dimaksud adalah hasil yang diperoleh berupa kesan-kesan yang mengakibatkan perubahan dalam diri individu sebagai hasil dalam aktivitas belajar. Prestasi yang baik bisa dicapai dengan menggunakan metode pembelajaran yang tepat (Syaiful Bahri, 1994:23).Sehingga secara tidak langsung kemampuan peserta didik dalam aspek: kemampuan mengemukakan pendapat, kemampuan mengenal masalah, kemampuan menuliskan pendapat-pendapatnya atau kelompoknya setelah melakukan pengamatan, kemampuan menyimpulkan, dan lain-lain dapat dikembangkan secara maksimal di dalam kelas( Zulfa, 2013 : 29 April) .Atas dasar itulah penulis mengambil judul "Implementasi Strategi Everyone is a teacher here Dalam Meningkatkan Prestasi Belajar Bidang Studi Quran Hadith Pada Siswa Program Akselerasi Kelas XI di MAN Kota Kediri 3.

Namun hal penting yang menjadi rumusan yang perlu diperhatikan adalah ;

1. Bagaimana prestasi belajar Quran Hadith pada siswa program akselerasi kelas XI di MAN Kota Kediri 3.

2. Bagaimana implementasi strategi everyone is a teacher here dalam bidang studi Quran Hadith pada siswa program akselerasi kelas XI di MAN Kota Kediri

3. Adakah peningkatan prestasi belajar Quran Hadist setelah diterapkannya strategi everyone is a teacher here pada siswa program akselerasi kelas XI di MAN Kota Kediri 3.

Penerapan Metode ini bertujuan untuk meningkatkan kualitas pembelajaran, sehingga peserta didik dapat aktif mengikuti seluruh proses belajar mengajar dengan baik dan maksimal. Manfaat dari Penelitian ini khususnya; 1) Bagi Penulis: dapat mengembangkan wawasan penerapan dalam mengaplikasikan teori yang didapatkan dengan kenyataan yang terdapat dilapangan dan menambah pengalaman. Lebih jauh lagi penulis dapat mengetahui strategi, media ataupun metode pembelajaran serta dapat menciptakan kondisi pembelajaran yang aktif, kreatif, dan inovatif. 2)Dengan adanya tindakan dan metode baru dari pendidik, maka siswa 
akan lebih aktif dalam proses pembelajaran, mengembangkan daya nalar serta mampu berfikir lebih kreatif sehingga siswa termotivasi untuk mengikuti proses pembelajaran dan dapat meningkatkan prestasi belajar, 3) Bagi Guru Dari hasil Penelitian dapat digunakan sebagai referensi dalam memilih dan menerapkan suatu metode yang sesuai dengan kompetensi pembelajaran, 4) Bagi Sekolah Bagi sekolah dapat digunakan sebagai bahan masukan dalam mengatur dan menetapkan kebijakan terkait dengan proses pembelajaran serta menambah pengetahuan pengembangan kurikulum dalam bidang pembelajaran.

\section{METODE PENELITIAN}

Penelitian ini menggunakan pendekatan kualitatif, yaitu suatu penelitian yang mendeskripsikan perilaku orang, peristiwa atau tempat tertentu secara terperinci dan mendalam. merupakan penelitian kualitatif naturalistik, istilah naturalistik menunjukkan bahwa pelaksanaan penelitian terjadi secara alamiah apa adanya, dalam situasi normal yang tidak dimanipulasi keadaan dan kondisinya serta menekankan pada deskripsi secara alami(Sugiyono. 2005). Sedangkan jenis penelitian yang digunakan adalah penelitian tindakan kelas (classroom action research), dengan jenis metode kolaboratif. Jenis penelitian kolaboratif yaitu hadirnya suatu kerja sama dangan pihak-pihak lain seperti atasan, teman sejawat, atau guru dengan peneliti. Penelitian Tindakan Kelas merupakan suatu proses dimana melalui proses ini gurudosen dan siswa-mahasiswa meningkatkan terjadinya perbaikan, peningkatan, dan perubahan pembelajaran lebih baik agar tujuan pembelajaran dapat tercapai secara optimal. Penelitian Tindakan kelas dapat didukung dengan menerapkan berbagai ragam teori dan teknik pembelajaran yang relevan secara kreatif (Ghony, 2008:1).

Penelitian ini dilaksanakan di Kediri 3 tahun pelajaran 2013/2014. Adapun waktu penelitian di mulai pada tgl 14 maret 2013, sedangkan subjek penelitian adalah siswa-siswi kelas XI program akselerasi dengan jumlah 19 siswa pada pelajaran Quran Hadis

Adapun sumber data dalam penelitian ini berbentuk kata-kata dan tindakan selebihnya adalah data tambahan seperti dokumentasi dan yang lain. Yaitu guru yang menerapkan metode every one is teacher pada mata pelajaran Quran Hadits, dan siswa-siswi kelas XI program akselerasi MAN Kota Kediri 3, karena peneliti menggunakan jenis penelitian tindakan kelas yang difok Pelaksanaan PTK ini di lakukan dalam beberapa siklus. Setiap siklus terdiri dari empat tahap, yaitu(1) Planning (rencana awal yang akan di lakukan), (2) Action (tindakan), (3) Observation (pengamatan), (4) Reflection (refleksi). Untuk memperoleh rekaman data yang akurat, kehadiran peneliti dalam penelitian ini adalah sebagai berikut: (1) Perencanaan kegiatan, (2) Pemberi tindakan, (3) Pengumpulan data, (4) Penganalisisan data, (5) Pelapor hasil penelitian. Kehadiran peneliti dilapangan adalah sebagai kunci penelitian, maka mutlak diperlukan. Karena desain penelitian yang dipilih adalah penelitian tindakan kelas yaitu dengan pendekatan kualitatif kolaboratif partisipatoris, maka dari itu selama penelitian tindakan ini dilakukan, peneliti bertindak sebagai observer, pengumpul data, penganalisis data, dan sekaligus pelapor hasil penelitian. Dalam penelitian ini, kedudukan peneliti sebagai perencana, pelaksana, pengumpul data, penganalisis data, dan pelapor hasil tindakan (Meleong,2001:121).

Instrumen yang digunakan dalam penelitian ini terdiri dari: (1)Tes. Tes ini dilakukan dengan menggunakan butir soal untuk mengukur hasil belajar siswa, baik kemampuan awal, perkembangan atau peningkatan selama tindakan berlangsung, dan kemampuan pada akhir siklus. (2) Metode Observasi, (3) Metode Interviw (wawancara) Wawancara ini ditujukan kepada kepala madrasah, guru, dan siswa MAN Kota KedirI 3. (4) Metode Dokumentasi(Arikunto, 2889:206). Dalam penelitian ini data yang diperoleh terdiri dari data kualitatif dan kuantitatif. Data yang diperoleh tersebut selanjutnya dianalisis secara deskriptif, yaitu Analisis Data Observasi Implementasi Strategi Everyone is a teacher here Pada Bidang Studi Quran Hadith, dengan criteria sebagai berikut:Sangat baik: diberi skor 4, Baik: diberi skor 3, Cukup: diberi skor 2, Kurang baik: diberi skor 1.

Adapun dalam pengolahannya dilakukan dengan cara sebagai berikut: (1) Menjumlahkan perolehan skor dari seluruh butir pertanyaan, (2) Mencari skor rata-rata dengan 
cara membagi jumlah perolehan skor oleh banyaknya pertanyaan. (3) Setelah itu, mencari nilai prosentasinya dengan cara membagi skor rata-rata dengan nilai maksimum $100 \%$. Dengan norma pengujian menggunakan skala prosentase dengan tingkat kriteria sebagai berikut: $90 \%$ $100 \%=$ sangat baik, $80 \%-89 \%=$ baik, $70 \%-79 \%=$ cukup, $60 \%-69 \%=$ kurang baik, $<60 \%$ $=$ sangat kurang baik.

\section{HASIL DAN PEMBAHASAN}

\section{A. Hasil}

Penelitian ini merupakan Penelitian Tindakan Kelas (PTK) yang dilaksanakan meliputi prosedur penelitian yang mencakup kegiatan menyusun perencanaan (planning), pelaksanaan tindakan (acting), pengamatan (observing), dan refleksi (reflecting). Keempat kegiatan ini berlangsung secara berulang dalam bentuk siklus.

Tahap-tahap Penelitian Tindaskan Kelas (PTK) ini dapat diimplementasikan kedalam sebuah skenario tindakan yang dilakukan peneliti sebagai berikut:

\section{Siklus I}

\section{1) Tahap Perencanaan}

Dalam tahap ini, dilakukan persiapan untuk tajhapa pelaksanaan tindakan. Persiapan tersebut, antara lain: (1) Menyusun rencana pengajaran dengan menggunakan strategi everyone is a teacher here. (2)Menentukan materi yang akan dipelajari.(3) Membuat rencana pembelajaran. (4) Menyusun lembar observasi. (5) Menyiapkan alat bantu atau sumber belajar. (6) Menentukan jadwal pelaksanaan tindakan.

\section{2) Tahap Pelaksanaan}

Melaksanakan langkah-langkah sesuai dengan perencanaan. (2) Memberi penjelasan teknis dan alur pembelajaran dengan menggunakan strategi everyone is a teacher here.

\section{3) Tahap Mengamati:}

Melakukan pengamatan. (2) Mengumpulkan data. (3) Melakukan diskusi dengan guru mata pelajaran untuk membahastentang kelemahan-kelemahan atau kekurangan-kekurangan yang dilakukan guru serta memberikan sarana perbaikan untuk berikutnya.

\section{4) Tahap Refleksi}

Menganalisis temuan saat melakukan observasi, Menganalisis kelemahan dan keberhasilan guru saat menerapkan strategi everyone is a teacher here dan mempertimbangkan langkah selanjutnya. Melakukan evaluasi.

\section{Siklus II}

Kegiatan perencanaan pada siklus II merujuk pada hasil pengamatan dan refleksi padas siklus I, dimana kekurangan-kekurangan selama pelaksanaan skenario tindakan kelas pada siklus I yang telah disusun dan dilaksanakan diberikan pembenahan dan perbaikan, sedngkan kelebihan-kelebihannya dipertahankan. Tahap Siklus II meliputi:

1) Tahap Perencanaan:

(1) Hasil refleksi dievaluasi, didiskusikan, dan mencari upaya perbaikan untuk, diterapkan pada pembelajaran berikutnya.

(2) Mendata masalah dan kendala yang dihadapi saat pembelajaran.

(3) Merancang perbaikan II berdasarkan refleksi siklus I.

2) Tahap Pelaksanaan:

(1) Melakukan analisis pemecahan masalah. 
(2) Melakukan tindakan perbaikan II dengan melaksanakan penerapan strategi everyone is a teacher here.

3) Tahap Mengamati:

(1) Melakukan pengamatan terhadap penerapan strategi everyone is a teacher here dengan memperhatikan hasil refleksi pada siklus I.

(2) Mencatat perubahan-perubahan yang berkaitan dengan aktivitas siswa selama proses pembelajaran berlangsung.

4) Tahap Refleksi:

Melaksanakan refleksi terhadap pelaksanaan pembelajaran dan hasil pengamatan pada siklus II.

\section{Kriteria Evaluasi dan Refleksi}

Dalam kegiatan PTK evaluasi yang dilakukan harus mencangkup meteri yang diajarkan ketika menerapkan metode yang telah dipilih. Sehingga terdapat kesinambungan materi antara proses dan hasilnya. Refleksi merupakan kegiatan yang dilakukan setelah evaluasi. Ketika suatu nilai yang dihasilkan telah mengalami perubahan menjadi lebih baik atau tidak terjadi perubahan maka peneliti harus menjadikan kegiatan sebelumnya menjadi pelajaran untuk perbaikan. Menurut Kunandar, refleksi adalah mengingat dan merenungkan suatu tindakan persis seperti yang telah dicatat dalam observasi.

Dalam refleksi terdapat kegiatan penting seperti: (1) Merenungkan kembali mengenai kekuatan dan kelemahan dari tindakan yang telah digunakan. (2) Menjawab tentang penyebab situasi dan kondisi yang terjadi selama pelaksanaan tindakan berlangsung. (3) Memperkirakan situasi atas keluhan yang muncul. (4) Mengidentifikasikan kendala atau ancaman yang mungkin dihadapi. (5) Memperkirakan akibat dan implikasi atas tindakan yang direncanakan.

Menurut Kunandar, refleksi terdiri atas 4 aspek yaitu: (1) Analisa data observasi. (1) Pemaknaan hasil analisis. (3) Penjelasan hasil analisis. (4) Penyimpulan apakah masalah itu teratasi atau tidak. Jika teratasi berapa $\%$ yang teratasi dan berapa persen yang belum teratasi. Jika ada yang belum teratasi apakah perlu dilanjutkan ke siklus berikutnya atau tidak. Jadi dalam refleksi akan ditentukan apakah penelitian itu berhenti disitu atau diteruskan.

\section{Pra- Siklus}

Berkaitan dengan implementasi atau penerapan strategi everyone is a teacher here, hasil analisis data tes siswa yang dilakukan pada pra siklus, dapat diketahui dari 19 siswa diperoleh nilai tertinggi 88 , nilai terendah 62 , nilai rata-rata 78 . Untuk sementara siswa yang tuntas masih mencapai 12 siswa dan yang tidak tuntas mencapai 7 siswa. Sehingga jika dianalisis lebih lanjut prosentase ketuntasan siswa, yaitu $12 / 19 \times 100 \%=63,15 \%$, ini artinya siswa belum dapat dikatakan tuntas karena jumlah siswa yang mencapai daya serap atau penguasaan materi adalah dibawah $75 \%$. Namun pencapaian ini masih belum maksimal dan perlu ditingkatkan, karena jika dilihat dari KKM (Kriteria Ketuntasan Maksimal) yang ditetapkan untuk Quran Hadith adalah 80. Maka ada 7 siswa yang belum memenuhi jumlah KKM (Kriteria Ketuntasan Maksimal). Hal ini sesuai dengan tabel berikut:

Tabel 1. Daftar Nilai

\begin{tabular}{|c|c|l|c|c|}
\hline No & $\begin{array}{c}\text { No. } \\
\text { Induk }\end{array}$ & \multicolumn{1}{|c|}{ Nama } & Nilai & Ketuntasan \\
\hline 1 & 8848 & A. Qodli Zakah & 78 & Tidak Tuntas \\
\hline 2 & 8849 & Abdil Haq Aqimuddin Q. & 82 & Tuntas \\
\hline 3 & 8850 & Ainur Rohmah & 84 & Tuntas \\
\hline 4 & 8851 & Ajeng Restiyo Rini & 60 & Tidak Tuntas \\
\hline 5 & 8854 & Devi Permatasari N & 76 & Tidak Tuntas \\
\hline 6 & 8856 & Fatimatus Sa'idah & 86 & Tuntas \\
\hline
\end{tabular}




\begin{tabular}{|c|c|l|c|c|}
\hline 7 & 8857 & Febri Daris F.R & 80 & Tuntas \\
\hline 8 & 8860 & Lia Zahrotun Nafisa & 80 & Tuntas \\
\hline 9 & 8861 & Luthfiana Fadhillah & 88 & Tuntas \\
\hline 10 & 8862 & Luthviyah Choirotul M & 84 & Tuntas \\
\hline 11 & 8863 & M Rofiul Hammam & 82 & Tuntas \\
\hline 12 & 8867 & Nabiilatul Arifah & 80 & Tuntas \\
\hline 13 & 8869 & Novenda Zephi Eka A & 80 & Tuntas \\
\hline 14 & 8873 & Rica Silvi Anastasia & 66 & Tidak Tuntas \\
\hline 15 & 8875 & Rizkita K. & 70 & Tidak Tuntas \\
\hline 16 & 8877 & Shandy Syahrizal A & 82 & Tuntas \\
\hline 17 & 8878 & Shinta Nisaus Syuroya & 88 & Tuntas \\
\hline 18 & 8879 & Sinta Dewi Ratih Sari & 62 & Tidak Tuntas \\
\hline 19 & 8880 & Uswah Ayu Wibawa & 74 & Tidak Tuntas \\
\hline \multicolumn{5}{|c|}{ Nilai Tertinggi } \\
\hline \multicolumn{5}{|c|}{ Nilai Terendah } \\
\hline \multicolumn{5}{|c|}{} \\
\hline
\end{tabular}

Tabel 2. Data Hasil Penilaian Proses Pengamatan Sikap Pada Siklus I

\begin{tabular}{|c|l|c|c|c|c|}
\hline No & \multicolumn{1}{|c|}{ Aktivitas yang dinilai } & KB & C & B & SB \\
\hline 1 & $\begin{array}{l}\text { Rasa keingintahuan siswa dalam } \\
\text { KBM }\end{array}$ & - & - & - & 4 \\
\hline 2 & Minat siswa dalam KBM & - & - & - & 4 \\
\hline 3 & Keaktifan siswa dalam KBM & - & - & 3 & - \\
\hline 4 & Keseriusan siwa dalam menghafal & - & - & 3 & - \\
\hline 5 & $\begin{array}{l}\text { Keberanian siswa mengemukakan } \\
\text { pendapat }\end{array}$ & - & - & 3 & \\
\hline 6 & $\begin{array}{l}\text { Kemampuan siswa dalam menjawab } \\
\text { pertanyaan }\end{array}$ & - & - & 3 & - \\
\hline Jumlah & - & - & 12 & 8 \\
\hline Jumlah perolehan skor & \multicolumn{3}{|c|}{30} \\
\hline Jumlah skor rata-rata & \multicolumn{3}{|c|}{ Baik } \\
\hline Nilai prosentase & & & \\
\hline Kriteria pengujian & & & \\
\hline
\end{tabular}

Tabel 3. Data Hasil Penilaian Proses Pengamatan Sikap Pada Siklus II

\begin{tabular}{|c|l|c|c|c|c|}
\hline No & \multicolumn{1}{|c|}{ Aktivitas yang dinilai } & KB & C & B & SB \\
\hline 1 & Rasa keingintahuan siswa dalam KBM & - & - & - & 4 \\
\hline 2 & Minat siswa dalam KBM & - & - & - & 4 \\
\hline 3 & Keaktifan siswa dalam KBM & - & - & - & 4 \\
\hline
\end{tabular}


Vol. 1 No. 2 Agustus 2021, e-ISSN : 2777-0575 P-ISSN : 2777-0583

\begin{tabular}{|c|c|c|c|c|c|}
\hline 4 & Keseriusan siwa dalam menghafal & - & - & 3 & - \\
\hline 5 & $\begin{array}{l}\text { Keberanian siswa mengemukakan } \\
\text { pendapat }\end{array}$ & - & - & 3 & \\
\hline 6 & $\begin{array}{l}\text { Kemampuan siswa dalam menjawab } \\
\text { pertanyaan }\end{array}$ & - & - & - & 4 \\
\hline \multicolumn{2}{|c|}{ Jumlah } & - & - & 6 & 16 \\
\hline \multicolumn{2}{|c|}{ Jumlah perolehan skor } & \multicolumn{4}{|c|}{22} \\
\hline \multicolumn{2}{|c|}{ Jumlah skor rata-rata } & \multicolumn{4}{|c|}{3,6} \\
\hline \multicolumn{2}{|c|}{ Nilai prosentase } & \multicolumn{4}{|c|}{$90 \%$} \\
\hline \multicolumn{2}{|c|}{ Kriteria pengujian } & \multicolumn{4}{|c|}{ Sangat Baik } \\
\hline
\end{tabular}

Tabel 4. Hasil Tes Sebelum Dan Sesudah Penelitian

\begin{tabular}{|c|c|l|c|c|c|}
\hline No & $\begin{array}{c}\text { No. } \\
\text { Induk }\end{array}$ & \multicolumn{1}{|c|}{ Nama } & $\begin{array}{c}\text { Pra } \\
\text { Siklus }\end{array}$ & $\begin{array}{c}\text { Siklus } \\
\text { I }\end{array}$ & $\begin{array}{c}\text { Siklus } \\
\text { II }\end{array}$ \\
\hline 1 & 8848 & A. Qodli Zakah & 78 & 78 & 90 \\
\hline 2 & 8849 & Abdil Haq Aqimuddin Q. & 82 & 82 & 82 \\
\hline 3 & 8850 & Ainur Rohmah & 84 & 84 & 87 \\
\hline 4 & 8851 & Ajeng Restiyo Rini & 60 & 80 & 81 \\
\hline 5 & 8854 & Devi Permatasari N & 76 & 80 & 81 \\
\hline 6 & 8856 & Fatimatus Sa'idah & 86 & 86 & 86 \\
\hline 7 & 8857 & Febri Daris F.R & 80 & 80 & 89 \\
\hline 8 & 8860 & Lia Zahrotun Nafisa & 80 & 80 & 92 \\
\hline 9 & 8861 & Luthfiana Fadhillah & 88 & 88 & 86 \\
\hline 10 & 8862 & Luthviyah Choirotul M & 84 & 84 & 85 \\
\hline 11 & 8863 & M. Rofiul Hammam & 82 & 82 & 91 \\
\hline 12 & 8867 & Nabiilatul Arifah & 80 & 80 & 93 \\
\hline 13 & 8869 & Novenda Zephi Eka A & 80 & 80 & 92 \\
\hline 14 & 8873 & Rica Silvi Anastasia & 66 & 80 & 81 \\
\hline 15 & 8875 & Rizkita K. & 70 & 80 & 88 \\
\hline 16 & 8877 & Shandy Syahrizal A & 82 & 82 & 87 \\
\hline 17 & 8878 & Shinta Nisaus Syuroya & 88 & 88 & 91 \\
\hline 18 & 8879 & Sinta Dewi Ratih Sari & 62 & 80 & 81 \\
\hline 19 & 8880 & Uswah Ayu Wibawa & 74 & 74 & 87 \\
\hline Nilai Tertinggi & 88 & 88 & 92 \\
\hline Nilai Terendah & 62 & 74 & 81 \\
\hline Nilai Rata-rata & 78 & 81,47 & 86,84 \\
\hline Nilai Ketuntasan dalam Prosentase & $63,15 \%$ & $89,47 \%$ & $100 \%$ \\
\hline
\end{tabular}

Hasil tes belajar siswa pada pembelajaran pra siklus dapat kita ketahui dari 19 siswa yang mencapai standar ketuntasan belajar sebanyak 12 siswa dengan nilai rata-rata 78 . Sehingga dapat diketahui tingkat ketuntasan siswa sebesar 63,15\%. 
Hasil tes siklus I dapat kita ketahui dari 19 siswa mencapai standar ketuntasan belajar sebanyak 17 siswa dengan nilai rata-rata 81,47. Sehingga dapat diketahui terjadinya peningkatan sebesar 26,32\% dengan tingkat ketuntasan siswa dalam prosentase sebesar $89,47 \%$. Kemudian melanjutkan siklus II dan dapat kita ketahui dari 19 siswa mencapai standar ketuntasan belajar sebanyak 19 siswa dengan nilai rata-rata 86,84. Sehingga dapat diketahui tingkat ketuntasan siswa sebesar $100 \%$. Adapun peningkatan keuntasan yang diperoleh adalah $10,53 \%$ dari siklus 1 . Dari sini dapat dikatakan bahwa semua siswa telah mampu mencapai standar ketuntasan belajar yang telah ditetapkan.

\section{Pembahasan}

Dalam bab ini akan dipaparkan pembahasan terkait dengan hasil paparan data dan temuan penelitan yang diperoleh dari hasil tes, wawancara, observasi, maupun dokumentasi. Dalam pembahasan hasil penelitian ini disajikan secara sistematis sesuai dengan teori-teori yang ada dan disesuaikan fokus penelitian agar lebih mudah dalam menganalisis setiap permasalahan yang ada, yakni prestasi belajar Quran Hadith pada siswa program akselerasi kelas XI di MAN Kota Kediri 3 sebelum diadakan penelitian, implementasi strategi everyone is a teacher here dalam meningkatkan prestasi belajar Quran Hadith pada siswa program akselerasi kelas XI di MAN Kota Kediri 3, dan peningkatan prestasi belajar Quran Hadith setelah diterapkannya stategi everyone is a teacher here pada siswa program akselerasi kelas XI di MAN Kota Kediri 3. Adapun hasil pembahasan dalam penelitian ini adalah sebagai berikut:

Prestasi Belajar Quran Hadith Pada Siswa Program Akselerasi Kelas XI di MAN Kota Kediri 3 sebelum diadakan penelitian dalam model penelitian tindakan kelas, langkah pertama yang harus dilakukan adalah melakukan perencanaan kemudian pelaksanaan tindakan. Dalam pelaksanaan ini terdapat kegiatan mengamati aktifitas selama pembelajaran. Dan yang terakhir melakukan analisis dan refleksi. Apabila metode yang digunakan berhasil maka bisa langsung ditarik kesimpulan. Namun apabila metode yang dilakukan masih perlu perbaikan maka dilakukan rencana selanjutnya, demikian terus berulang sampai metode yang digunakan benarbenar berhasil. Sebagaimana yang diungkapkan oleh M. Djunaidin Ghony dalam bukunya Penelitian Tindakan Kelas bahwa Penelitian Tindakan Kelas merupakan suatu proses dimana melalui proses ini guru-dosen dan siswa-mahasiswa meningkatkan terjadinya perbaikan, peningkatan, dan perubahan pembelajaran lebih baik agar tujuan pembelajaran dapat tercapai secara optimal (Ghony,2008:1).

Langkah awal sebelum tindakan dilaksanakan, peneliti harus melakukan pra tindakan. Kegiatan ini dilakukan untuk mengetahui kemampuan siswa sebelum tindakan dilakukan. Pada tahap pra tindakan, peneliti melakukan refleksi dalam pembelajaran Quran Hadith. Hasil penelitian menunjukkan bahwa metode yang dilakukan kurang bisa mengikut sertakan semua siswa, sehingga banyak siswa sibuk sendiri setelah hafalan. Berdasarkan kenyataan itulah, hanya sebagian kecil dari siswa yang aktif selama KBM berlangsung. Pada tahap pra tindakan ini, peneliti memberi tes awal berupa pemberian soal dengan tujuan mengetahui kemampuan siswa dalam mata pelajaran Quran Hadith. Tahap awal ini memfokuskan pada aspek ingatan, pemahaman, penerapan, dan analisis.

Dari hasil tes pada kegiatan tersebut diketahui bahwa siswa belum sepenuhnya bisa menyerap pelajaran yang telah disampaikan mencapai ketuntasan. Dengan hasil tes dipereoleh nilai tertinggi 88, nilai terendah 62, dan nilai rata-rata 78. Maka dapat diketahui dari 19 siswa ada 12 siswa yang tuntas dan 7 siswa belum tuntas dalam memenuhi Kriteria Ketuntasan Maksimal (KKM) yaitu 80. Sehingga jika dianalisis lebih lanjut, yaitu 12/19 x 100\% =63,15 $\%$, ini artinya siswa belum dapat dikatakan tuntas karena jumlah siswa yang mencapai daya serap atau penguasaan materi adalah dibawah $75 \%$.

Penelitian tindakan kelas yang dilakukan oleh peneliti terdiri atas dua siklus, yang dalam tiap siklus terdapat empat tahapan yaitu perencanaan, pelaksanaan, observasi, dan refleksi. Hasil refleksi ini dijadikan dasar untuk menentukan keputusan perbaikan pada siklus 
berikutnya. Penelitian tindakan kelas ini dilakukan dengan cara menerapkan strategi everyone is a teacher here.

Strategi everyone is a teacher here yaitu strategi yang dapat digunakan untuk meningkatkan proses pembelajaran siswa, dan dapat disesuaikan dengan tujuan yang ingin dicapai oleh pembelajaran pada berbagai mata pelajaran, khususnya mencapaian tujuan yaitu meliputi aspek: kemampuan mengemukakan pendapat, kemampuan mengenal masalah, kemampuan menuliskan pendapat-pendapatnya atau kelompoknya setelah melakukan pengamatan, kemampuan menyimpulkan, dan lain-lain. Dalam proses belajar tidak harus berasal dari guru, siswa bisa saling mengajar dengan siswa yang lainnya. Strategi ini merupakan strategi mudah untuk mendapatkan partisipasi seluruh kelas dan pertanggung jawaban individu. Strategi ini memberikan kesempatan bagi setiap siswa untuk bertindak sebagai guru bagi siswa lain.

Penerapan strategi everyone is a teacher here yang dilakukan selama 2 kali pertemuan, yang mana untuk pertemuan pertama peneliti melakukan pra siklus pada tanggal 2 April 2013. Pada tanggal 30 April 2013 dan 7 Mei 2013 merupakan pertemuan kedua dan ketiga bagi peneliti untuk melakukan pelaksanaan penelitian tindakan kelas dilakukan selama jam pelajaran setiap hari selasa jam 08.30-10.00.

Berdasakan hasil tes siswa yang dilakukan pada siklus I, dapat diketahui dari 19 siswa, banyaknya siswa yang tuntas ada 17 siswa dan yang belum tuntas 2 siswa. Dengan nilai tertinggi 88 , nilai terendah 74 , dan nilai rata-rata 81,47 . Jika dianalisis lebih lanjut maka prosentase siswa yang tuntas sebanyak $17 / 19 \times 100 \%=89,47 \%$. Maka jika dilihat dari daya serap siswa sudah dapat dikatakan tuntas dengan prosentase diatas $75 \%$. Tetapi masih ada 2 siswa yang belum tuntas apabila dilihat dari KKM yang ditentukan oleh sekolah yaitu 80 .

Selanjutnya siklus II dapat kita lihat bahwa dari 19 siswa sudah mencapai ketuntasan 100\%. Sehingga jika dianalisis lebih lanjut prosentase ketuntasan siswa, yaitu 19/19 x 100\%= $100 \%$, ini artinya siswa sudah dapat dikatakan tuntas karena jumlah siswa yang mencapai daya serap atau penguasaan materi adalah diatas $75 \%$. Dengan nilai tertinggi 92 , nilai terendah 81 , dan nilai rata-rata 86,84 terdapat peningkatan sebesar $10,53 \%$. Maka hal ini dapat diketahui bahwa siswa telah mencapai daya serap atau penguasaan materi sesuai dengan ketuntasan maksimal.

Dalam pengamatan KBM ketika menerapkan strategi everyone is a teacher here (semua bisa jadi guru) telah mencapai kriteria sangat baik, hanya saja keseriusan siswa dalam menghafal dan cara mengemukakan pendapat masih mendapatkan nilai 3 (baik) dan aspek lainnya mendapatkan nilai 4 (sangat baik). Dari hasil analisis dapat disimpulkan bahwa, pembelajaran dengan menggunakan strategi everyone is a teacher here (semua bisa jadi guru) berhasil dan berjalan dengan baik. Pada penerapan strategi everyone is a teacher here suasana kelas dibentuk seperti semula tetap menghadap kedepan dan siswa lebih terlihat semangat sebab dalam penerapan strategi ini di variasikan dengan pemberian tugas pada siswa secara berkelompok. Masing-masing kelompok 3-4 orang, adapun tugas yang diberikan meliputi menuliskan ayat beserta arti, penjelasan ayat, kata inti, tafsir, kesimpulan dan pemberian contoh berupa vidio tentang kelestarian lingkungan sesuai dengan isi kandungan ayat dan tugas ini dipresentasikan dengan menggunakan power point.

Dalam hal ini setiap kelompok harus menjelaskan materi yang menjadi tugasnya di hadapan teman-teman dan menjawab pertanyaan yang telah diberikan oleh kelompok lain. Selain itu adanya media pembelajaran yang mendukung proses pembelajaran yang berlangsung karena ada kerjasama yang baik. Dalam penyampaian materi ada juga siswa yang masih gugup.

Berdasarkan hasil observasi peneliti yang terdapat pada hasil tes dengan strategi everyone is a teacher here adalah bahwa implementasi strategi everyone is a teacher here dapat meningkatkan prestasi belajar siswa kelas XI-A program akselerasi di MAN Kota Kediri 3 tahun pelajaran 2013. Bahwa siswa tekun dan antusias selama proses pembelajaran, aktif selama proses pembelajaran, dan aktif dalam mengerjakan tugas, serta disiplin dalam proses pembelajaran. Proses pembelajaran yang lebih mudah dalam pemahaman materi ajar akan 
berdampak pada hasil belajar siswa. Penelitian yang dilakukan oleh peneliti yang bertindak sebagai observer menyatakan bahwa aktivitas guru adalah baik pada siklus I dan sangat baik pada siklus II. Hal ini dipandang sesuai dengan kenyataan dimana aktifitas guru banyak berfungsi sebagai fasilitator yang melayani para siswa, baik dalam menjelaskan konsep pembelajaran maupun teknis operasional perangkat pembelajaran.

Peningkatan Prestasi Belajar Quran Hadith Setelah Diterapkannya Strategi Everyone is a teacher here Pada Siswa Program Akselerasi Kelas XI di MAN Kota Kediri 3

Berdasarkan hasil observasi peneliti terhadap nilai yang diperoleh siswa baik sebelum dan sesudah pelaksanaan strategi everyone is a teacher here dapat diketahui dari hasil tes.

Tabel 5. Hasil Pra Siklus, Siklus I, Siklus II

\begin{tabular}{|l|c|c|c|}
\hline Aspek Penilaian & Pra Siklus & Siklus I & Siklus II \\
\hline Nilai Tertinggi & 88 & 88 & 92 \\
\hline Nilai Terendah & 62 & 74 & 81 \\
\hline Nilai Rata-rata & 78 & 81,47 & 86,84 \\
\hline Nilai Ketuntasan dalam Prosentase & $63,15 \%$ & $89,47 \%$ & $100 \%$ \\
\hline
\end{tabular}

Hasil tes belajar siswa pada pembelajaran pra siklus dapat kita ketahui dari 19 siswa yang mencapai standar ketuntasan belajar sebanyak 12 siswa dengan nilai rata-rata 78. Sehingga dapat diketahui tingkat ketuntasan siswa sebesar 63,15\%. Hasil tes siklus I dapat kita ketahui dari 19 siswa mencapai standar ketuntasan belajar sebanyak 17 siswa dengan nilai ratarata 81,47. Sehingga dapat diketahui terjadinya peningkatan sebesar 26,32\% dengan tingkat ketuntasan siswa dalam prosentase sebesar $89,47 \%$. Kemudian melanjutkan siklus II dan dapat kita ketahui dari 19 siswa mencapai standar ketuntasan belajar sebanyak 19 siswa dengan nilai rata-rata 86,84. Sehingga dapat diketahui tingkat ketuntasan siswa sebesar $100 \%$. Adapun peningkatan keuntasan yang diperoleh adalah 10,53\% dari siklus 1 . Dari sini dapat dikatakan bahwa semua siswa telah mampu mencapai standar ketuntasan belajar yang telah ditetapkan.

Selain itu dapat dilihat dari KBM (Kegiatan Belajar Mengajar), diantaranya yaitu: Prestasi siswa pada pelajaran Quran Hadith menjadi meningkat dengan dilakukannya strategi yang sesuai dengan yang telah diterapkan, Siswa kelihatan lebih aktif dalam kegiatan belajar mengajar, dalam arti tidak ada siswa yang ngobrol atau bermain sendiri ketika guru atau teman memberikan penjelasan, Siswa kelihatan kreatif dengan adanya pemberian tugas yang ditampilkan untuk presentasi, Selalu berusaha menjawab tugas dengan mencari sumber belajar yang lain, Siswa menyelesaikan tugas tepat waktu dan perlengkapan belajar selalu dibawa.

\section{KESIMPULAN}

Pembelajaran dengan menggunakan metodee everyone is a teacher here. (ETH) memiliki dampak yang positif. Dalam proses belajar tidak harus berasal dari guru, siswa bisa saling mengajar dengan siswa yang lainnya. Strategi ini merupakan strategi mudah untuk mendapatkan partisipasi seluruh kelas dan pertanggung jawaban individu. Strategi ini memberikan kesempatan bagi setiap siswa untuk bertindak sebagai guru bagi siswa lain. Cara ini bisa dilakukan untuk pengajaran ketrampilan membaca, unsur-unsur bahasa seperti tata bahasa. Dengan melihat strategi everyone is a teacher here dan ayat diatas sangat berhubungan karena dengan strategi itu membuat siswa dapat dididik dan dapat mendidik.

Berdasarkan hasil penelitian itu banyak kemajuan yang dapat dilihat dari KBM (Kegiatan Belajar Mengajar), diantaranya yaitu: (1) Prestasi siswa pada pelajaran Quran Hadith menjadi meningkat dengan dilakukannya strategi yang sesuai dengan yang telah diterapkan; (2) Siswa kelihatan lebih aktif dalam kegiatan belajar mengajar, dalam arti tidak ada siswa yang ngobrol atau bermain sendiri ketika guru atau teman memberikan penjelasan; (3) Siswa kelihatan kreatif dengan adanya pemberian tugas yang ditampilkan untuk presentasi; (4) Selalu 
berusaha menjawab tugas dengan mencari sumber belajar yang lain; (5) Siswa menyelesaikan tugas tepat waktu dan perlengkapan belajar selalu dibawa.

\section{DAFTAR PUSTAKA}

Arikunto,Suharsimi. (2011). Prosedur penelitian : suatu pendekatan praktik. (Ed. Rev. VI, Cet. 14). Jakarta : Rineka Cipta

Djamarah, Syaiful Bahri. (1994). Prestasi Belajar dan Kompetensi Guru. Surabaya: Usaha Nasional.

Fattah, Nanang. (1996). Landasan Manajemen Pendidikan. Bandung: Remaja Rosdakarya. Ghony. M. Djunaidin. (2008). Penelitian Tindakan Kelas. Malang: UIN Malang Press.

Machmudah, Umi. (2008). Active Learning dalam pembelajaran Bahasa Arab. Malang: UINMalang

Meleong, Lexy J. 2001. Metodologi Penelitian Kualitatif. Bandung: Remaja Rosdakarya.

Ramayulis. (2015). Metodologi Pendidikan Agama Islam. Jakarta: Kalam Mulia.

Slameto. (2003). Belajar dan Faktor-Faktor yang Mempengaruhinya. Jakarta: Rineka Cipta.

Sugiyono. (2008). Metode Penelitian Pendidikan; Pendekatan Kuantitatif, Kualitatif, dan $R$ \& $D$. Bandung: Alfabeta.

Sunartombs. (2017, 27 Oktober). Pengertian Prestasi Belajar, Wordpress on line, http://www.wordpress.com, 05 Januari 2009.

Suprijono, Agus. (2012). Cooperatif Learning. Yogyakarta : Pustaa Pelajar.

Zulfa, Nazwad. (2017, 29 April) "Pembelajaran Everyone is a Teacher Here". word press on line http://nazwadzulfa.wordpress.com/2009/09/30/pembelajaran-every-one-is-ateacher-here/. 